\title{
A Popperian Perspective on Science Education
}

\author{
Margaret A.L. Blackie (Corresponding author) \\ Department of Chemistry and Polymer Science, Stellenbosch University
}

De Beers Building, Matieland 7602, South Africa

Tel: 27-21-808-3353 E-mail: mblackie@sun.ac.za

Received: April 9, 2012

doi:10.5430/ijhe.v1n1p160
Accepted: May 2, 2012

URL: http://dx.doi.org/10.5430/ijhe.v1n1p160

Published: May 15, 2012

\begin{abstract}
Despite the rigorous debate around the purposes of higher education and the associated concept of graduate attributes, science education at the tertiary level has remained largely impervious to engaging with these ideas. This is may be due to the emphasis on the knowledge base of the hard science as opposed to the emphasis on the knower in the humanities. However, many science graduates leave tertiary institutions with a fairly simplistic epistemology despite the rhetoric of the importance of problem solving and conceptual understanding. Arguments stemming from an emphasis on the being of the student are easily dismissed by scientists as being irrelevant or substantially less important than the content knowledge of their subjects. In exploring the philosophy of Karl Popper an argument can be made for the importance of personal development on the basis of Popper's understanding of critique.
\end{abstract}

Keywords: Popper, Critique, Science education, Personal development, Being

\section{Introduction}

The debate around the purpose of higher education continues formally in the literature (Altbach, Reisberg, \& Rumbley, 2009; Barnett \& Griffin, 1997; Bok, 2003; Mann, 2008; Readings, 1996) and informally in the tea rooms, hallways and offices of higher education institutions. As more and more students find access to and participate in higher education, questions around the meaning and value of higher education become increasingly complex and increasingly important. Institutionally, this arena is crystallizing around the, so-called, graduate attributes (Barrie, 2004; Green, Hammer, \& Star, 2009). Where graduate attributes once dealt with the kind of student who chose to go to particular institutions, they were perhaps a little easier to distinguish - the 'Oxford man' of the 1930's conjures a clear mental image (cf Maton, 2007). But as the student cohort entering the system continues to diversify, their attributes as they leave the system are less easily identifiable. As the absolute cost of higher education is also increasing, we must seriously question the 'added value' of higher education (Liu, 2009; Marginson \& Rhoades, 2002; Sparks, 2011). Barnett's call for a focus on 'being' speaks directly to this issue (Barnett, 2008, 2009). Although there is a strong economic drive for a defined skill and knowledge set (Mann, 2008), in an era when people are far more mobile in terms of their career path (Hall, 1996), higher education which limits itself to this level of function does not necessarily serve its graduates as well as it could.

In the science education literature these kinds of conversations are almost totally absent. Although it can be argued that incorporating the skills of following, developing and defending a rational argument are crucial elements of science education (Bricker \& Bell, 2008). Indeed, it is these skills which directly impact a person's ability to participate consciously and rationally in a democratic society (Nussbaum, 2006). Furthermore, the ability to participate in an intelligent, critical conversation requires a degree of personal and intellectual maturity. Along with this, for science graduates, it is important to understand the particular form of knowledge that comprises science, together with an appreciation of the roles of other forms of knowing.

In this paper some Popperian principles are explored and examined as ways to hold together the essence of a good science education together with the broader purposes of higher education. This points towards a model of education which prepares students not only for work in particular knowledge fields, but also for participation in civic society. The association between quality education and participation in a democratic society has been long asserted. One such example is the work of John Dewey. Dewey, one of the giants of progressive education in the early twentieth century, was very clear that a functioning democracy was dependent on the quality of education (Westbrook, 1993). Karl Popper is well known in political science for his idea of the importance of critique in a functioning democracy (Magee, 1974). 


\section{Graduate attributes in science education}

Walker argues that university education should comprise three dimensions: 'personal development, economic opportunities and fostering educated citizens' (2008, p. 478). If one examines graduates who hold a bachelor's degree in science one may well question the efficacy of undergraduate curricula with respect to Walker's first and third dimensions. Felder and Brent (2004a) argue that science graduates persistently emerge from undergraduate education with a more simplistic understanding of the nature of knowledge than their counterparts in the social sciences and humanities. This seems slightly odd if one accepts at face value the emphasis placed on the ideals of critical thinking and problem solving which are so prevalent in the rhetoric associated with science degrees. Perhaps one of the issues here is the strong valuing of specific knowledge and skill sets, which may come at the expense of personal development in science education. A cursory search of the Journal of College Science Teaching over the period 1997-2010 (approximately 1000 papers ) on the key phrases or words 'graduate attributes' ( 0 hits); 'personal development' (5 hits); 'citizen' (10 hits); and 'agency' (6 hits) contrasts sharply which a more general higher education journal. In Teaching in Higher Education over the same period (approximately 840 papers in total): 'graduate attributes' (14 papers); 'personal development' ( 83 papers); 'citizen' (49 papers); and 'agency' (144 papers). From this very superficial survey, it is immediately apparent that, apart from a tiny minority, there is little engagement in science education with the idea of personal transformation. Nonetheless, few university based scientists would argue against the concept of the university postulated by Bowden and Marton: '.. the university is not primarily about the reproduction of the collective mind (i.e. the complex of all the ways in which we are capable of thinking about the world), but it is about expanding, widening and transforming the collective mind' (1998, p. 5). But one might ask whether such a transformation of the collective mind is possible if one pays no attention to individual transformation. Dewey (1963) suggests that if one fails to identify the desired ends of one's education system, then one is unlikely to achieve them.

Popper (2002) postulates that knowledge progresses best through critique. In asserting this position one can argue that the ability to articulate one's position and to engage in a critical conversation about this position requires substantial interpersonal skills. With this in mind, perhaps one would do better to frame the goal of science education in terms of the development not simply of scientists, but of 'scientist citizens'. Using Mann's terms (2008, p. 139), we are not simply looking for graduates who are 'inquiry-driven and capable of critique, analysis and reflection' but graduates who are also 'confident, vital and resilient; ... and capable of informed and effective action in collaboration with others'. That is to say, it is important that we find a way to value personal development if our science graduates are to be more effective scientists. An effective scientist is not simply knowledgeable about science, but is able to interact with society as a scientist. In raising the idea of 'scientist citizens' we may find a way to hold Walker's three dimensions of a university education (2008) without resorting to explicit inclusion of 'soft skills' which are so easily eliminated from curricula under the continual pressure from an exponentially increasing information set. Such a notion is only defensible if it can be demonstrated that science education could be improved if some attention is given to personal development. The philosophy of Karl Popper can provide this foundation.

\section{Knowledge in science education}

The focus of this paper is on science education. The aim is to explore how knowledge is used, developed and passed on within a scientific paradigm. Popper distinguishes between 'science' and 'non-science' and focuses his efforts on knowledge in science (Popper, 2002). Before engaging with the key Popperian principles it may be worthwhile to briefly explore the way in which knowledge is understood in science. The broad strokes of the ideological debates around the primary purpose of higher education often fail to acknowledge the difference between the ways in which 'knowledge' itself is understood in different disciplines. In the hard sciences, (Becher \& Trowler, 2001) knowledge is often presumed to be independent of the one who knows, indicating an underlying belief that a bit of information 'known' by two different individuals is the same. This is in contrast to the 'soft sciences' where the knower becomes more significant. Maton (2000) refers to the distinction between the 'knowledge mode of legitimation' and the 'knower mode of legitimation'. Disciplines which have a knowledge mode of legitimation claim that 'anyone can produce knowledge provided they comply with [the defined] extra-personal practices'(Maton, 2000, p. 156). Conversely, in disciplines which have a knower mode of legitimation, 'claims to knowledge by actors within the intellectual field are legitimated by reference to the knower's subjective or inter-subjective attributes and personal experiences' (Maton, 2000, p. 157). The hard sciences would fall squarely into Maton's 'knowledge mode' of legitimation as opposed to 'knower mode' of legitimation (2000). That is to say, that the knower has little impact on what is known. In the social sciences, the way in which the knower interprets the information is far more consciously understood to have an impact on what is known. It is hardly surprising then, that in science education the knower and, by association, ideas of personal development and citizenship are perceived to be the poor cousins of the favoured heir 'knowledge'. Hence the exploration of the integration of these 'knower' focused ideas is of marginal interest in science education research. 


\section{Key Popperian tenets}

Karl Popper is strongly associated in scientific circles with a substantial critique on logical positivism. In politics, he is remembered for his critique on Marx and in philosophy, for his strong attack on Plato (Magee, 1974). Although his work has itself been critiqued, refined and occasionally refuted, he is counted as one of a handful of influential philosophers of the mid-twentieth century. His critical rationalist stance provides something of a middle road between rationalism (knowledge grows through reason) and empiricism (knowledge grows through experience). For Popper neither approach is adequate on its own. Critical rationalism insists that both reason and experience are necessary for the growth of knowledge (Parton \& Bailey, 2008). Popper wrote extensively on society, science and knowledge, and underpinning his arguments and critiques are a few fundamental attitudes which throw an interesting light on education.

4.1 Problem solving: Popper argues that problem solving is a primal activity - a driving force for evolution. The principal problem to be solved in this sense is survival. For education this raises an interesting possibility - problem solving is an innate human quality. The role as educator is not so much to 'teach' problem solving as to provide an environment in which the innate problem solving ability of students is evoked. It is important to acknowledge the significance of this mind-shift. If we have confidence in the students' ability to solve problems, then we can rely on this skill when we teach. The focus and emphasis of our teaching will naturally change. The focus becomes trying to provide a curriculum which draws on this natural ability which then aids the momentum of learning. The issue of problem solving can be understood at two different levels. First, on the level of the curriculum content: for Popper all learning is a problem solving activity. In the first instance, on hearing a new fact, the problem to be solved is how one categorises the information with respect to pre-existing mental categories; does this confirm or challenge what I have previously held to be true. Secondly, problem solving is relevant to how the key players engage with the material. The primary problem for the student is successfully negotiating the hurdles of assessment. The well documented phenomenon of 'surface learning' (Marton \& Säljö, 1984) is a solution, albeit one which is pedagogically inferior, to this particular hurdle. The influence of assessment of the depth or quality of learning has also been established, although it is perhaps a little naive to presume that simply altering assessment may dramatically affect the outcomes of any particular course (Shay, 2008). Nonetheless, it is useful for the educator to examine how one might frame assessment in such a way that a deeper approach to learning is truly rewarded. An example of this is the introduction of questions which explicitly test conceptual understanding rather than the more traditional application type questions. Mazur and co-workers $(2001 ; 2002)$ have shown the efficacy of this approach in first year physics courses. Students able to perform complex mathematical operations failed to perform well on the force concept inventory whilst managing to pass standard examinations. This indicates that the ability to produce the correct answer using the appropriate algorithm does not necessarily correlate with correct conceptual understanding. However, good performance in conceptual tests is strongly associated with performance in more traditional testing. In the physical sciences, whilst we claim to prize conceptual understanding, critical thinking and problem solving abilities, we frequently do not assess in a way which rewards these abilities.

4.2 Critique: Popper argues that knowledge is only advanced through critique. This idea overlaps with the importance of problem solving, but critique requires conscious reflection which simple problem solving does not. This is, therefore, a separate category for consideration. Furthermore critique, as it is envisioned by Popper, requires engagement with another. This means that knowledge is best constructed in a social context. Note, this is not necessarily to hold the postmodernist viewpoint that because knowledge is socially constructed it is ultimately subjective. For Popper (1978), there is such a thing as objective knowledge and it resides in his 'World 3'. The Popperian cosmology envisions three 'worlds'. World 1 is the world of physical objects and physical energy. Biological entities interact in World 1. World 2 is the mental or psychological world. This is the world in which emotion, thoughts and perceptions exist, for example, human suffering. World 3 is the world of products of the human mind. Language, scientific theory, art and feats of engineering would all exemplify World 3 (Popper, 1978).

A truly Popperian education system must prepare students for intellectual engagement with others. The goal of a Popperian education would not be autonomy i.e. the ability to work alone, but rather the ability to work independently in a context in which all knowledge is tested in community through critique. This critique of knowledge comes in two different forms. Firstly, for those ideas which can be tested practically, experiments must be devised to disprove the idea. The strength or credibility of an idea comes from the failure of a variety of such experiments. Inevitably the idea should be tested by more than simply the person who generated the idea. Secondly, for those ideas that cannot be proved or disproved experimentally, the use of rational argument must be employed. The weakest point of the idea must be thoroughly probed by counter arguments in order to determine whether it actually holds. Again, it is often difficult for most people to develop the strength of counterargument required for this probing against one of their own ideas. The importance of an exchange with others is vital in this respect. It could be noted here, that if one is to take the brief 
encounter with Wittgenstein as illustrative of Popper's ability to engage in such dialogue, then perhaps Popper was not the best disciple of his own work (Edmonds \& Eidinow, 2001)! (Note 1)

In terms of establishing an educative environment several points emerge from the idea of critique. Firstly, as has been well established, reflection is an important part of the learning cycle (Dewey, 1933). Secondly, this challenges the educator to take the stance of one who has explored the intellectual territory to a greater extent, rather than one who knows everything in the intellectual territory. It allows for the possibility that the knowledge and understanding of all participants in the educative process may develop and grow as knowledge and information are grappled with. Mann argues that academic practice must be the process of trying 'to make sense of the world and ourselves in it for the purposes of developing and communicating understanding in order to act in and on the world for the better' (2008, $p$. 139). For Popper, this is philosophy and every human person is a philosopher. Philosophy is an inescapable activity of any human being, because the critical examination of our presumptions is a moral and intellectual imperative (Magee, 1974).

4.3 Science v non-science: Popper distinguishes science from non-science (Magee, 1974). This is in marked contrast to the attitude so prevalent in many of the popular science writers of today who seem to juxtapose science with nonsense. This attitude, known as scientism, is an ideology which holds that anything that cannot be defended scientifically i.e. is possible to falsify in principle, is indefensible. The implication is that science provides the only portal to knowledge of the world. Popper's distinction between science and non-science allows for the valuing of knowledge which is not scientific. For Popper there are two issues at stake. Firstly, science is founded on rational argument and secondly, scientific postulation is subject to all possible testing particularly those tests which will refute the postulation. The possibility of refutation is a subset of the broader basis of rational argument. Popper is quick to acknowledge that holding a rational worldview requires an irrational holding of that belief. This is the heart of the position which he terms 'critical rationalism'. Those who hold rationalism without an acknowledgement of the limitations of the rational process hold what Popper terms an 'uncritical or comprehensive rationalism' (Popper in Miller, 1983). This attitude is perhaps most clearly illustrated in the powerful argument against religion of Richard Dawkins, most notably in The God Delusion. This book is rationally well argued, if one forgives the occasional sweeping statement as good rhetoric, but anything which cannot be defended on a scientific basis is dismissed out of turn. Few would dispute that the understanding that we have of the cosmos today is principally attributable to scientists of all ilk and era. In the context of this paper, the valuing of personal development in science education would be classified as non-science. In a broader sense, there are many disciplines which contribute significantly to humanity which are not properly scientific. Of these, perhaps one which most closely impinges upon scientific research is the area of ethics. Ethical decisions are not scientific, although some elements of any particular ethical argument may be defended in rational terms. Whilst some scientists may not like particular decisions made by ethics committees which may hinder their research efforts, there are probably only a very small minority of scientists who would not see the value of ethics despite its lack of rational credibility. One cannot defend the value of ethics scientifically. Popper himself acknowledges that whilst rationalism is very useful, and indeed fundamental to progress in science, it has a limited sphere of application. Adherence to a 'comprehensive rationalism' rather than a 'critical rationalism' (Popper in Miller, 1983) results in the undervaluing of those aspects of human discovery which are not 'scientific'. From there it is a relatively short step to scientism. The problem here is that once we have elevated the rational aspects of humanity above the relational, the 'being' so earnestly argued for by Barnett (2008), slips from our grasp. Science is fundamentally important but we must understand that it is not everything. Scientism itself arises out of an irrational value judgment.

This is not to say that 'being' will be found by pursing knowledge through an irrational process. On the contrary, the ability to follow a rational argument and judge the quality of an argument in rational terms is a crucial part of citizenship (Magee, 1974; Westbrook, 1993). Furthermore engaging in the process of coming to know may well have an influence on the 'being' of a person (Barnett, 2009). Who among the highly educated would not argue that the world would be a better place if the outcome of political elections were based on the strength of the candidates' arguments, rather than the force of personality? There are multiple examples which are less emotionally charged which can illustrate this point. One such example is the burgeoning in marketing of 'chemical free substances' which is related to what can arguably described as a reemergence of the vital force theory (Bourne, 2009). The basic premise being that a specific molecule made in a plant or animal is deemed to have special qualities despite being chemically indistinguishable from the laboratory synthesized equivalent. The rational argument is simply ignored despite the scientific evidence. The real problem with an irrational stance is that it cannot be critiqued rationally because the foundations of the viewpoint are not open to inspection. All higher education, if it is to be truly useful, must attend to a sound grasp of the difference between science and non-science. Key assumptions and creative leaps are a legitimate and important aspect of scientific progress. They allow us to progress, to move beyond the bounds of what is already known (Miller, 1983). But in themselves, such 
creative leaps are not science. Their anecdotal presence in the history of science help guard against pure scientism, but they cannot stand alone.

\section{Models of intellectual development}

Intellectual growth has been wryly described by Kroll as 'the development from ignorant certainty to intelligent confusion' (Felder \& Brent, 2004a). In the stage of ignorant certainty, knowledge is crudely divided into two broad categories, that which is certain and that which is unknowable. Science is therefore 'certain', and its certainty is provided by the authority of the educator. The student's task is to get to grips with the package of certain knowledge required by any specific course. There are a number of well-established typologies which track the different stages of intellectual development. Perry's model (1970) delineates nine stages which can been grouped into three epistemological positions (West, 2004): dualism (stages 1-2); multiplicity (stages 3-4); and relativism (stages 5-9). The terms used here in the Perry model are slightly awkward to use in a hard science setting where relativism is not seen in a positive light. The Baxter-Magolda typology (1992) gives four epistemological positions absolute knowing; transitional knowing; independent knowing and contextual knowing which are slightly easier to apply directly to a hard science context. Absolute knowing correlates to Perry's stage 2; transitional knowing to Perry's stage 3; independent knowing to Perry's stage 4 and contextual knowing covers Perry's stages 5-6 (Felder \& Brent, 2004a). In both cases the trajectory begins with ' a state of simple, absolute certainty' and develops 'into a multifaceted, evaluative system' (West, 2004, p. 61).

The Popperian emphasis on the importance of critique in the development of ideas is consistent with the 'contextual knowing' stage of the Baxter-Magolda typography. In the stage of contextual knowing, several important elements converge: the ability to development a rational argument to support the idea; the willingness to seek evidence to support the idea; a degree of comfort with the fragility to the model proposed i.e. the model is a 'best-fit' for the moment, but a marginally more robust model is likely to be proposed at some point in the future (Felder \& Brent, 2004a). This mirrors a Popperian framework - the importance of rational argument which is subjected to external critique; the need for a scientific approach to any scientific hypothesis i.e. experiments which will potentially nullify the hypothesis should be actively investigated; and a level of comfort with the idea that all knowledge is incomplete as evidence or theory may emerge at any time which radically alters the way in which we view this particular model. The only caveat here is that for Popper, nullification of the hypothesis would require a complete rethinking. Lakatos and other philosophers with Popperian roots take a slightly softer approach and place greater emphasis on the improvement of a hypothesis by increment.

Drawing from Dewey (1963), unless we are conscious of the importance of fostering intellectual development, in addition to content knowledge, in our undergraduate science courses, we are likely to fail in our intention to facilitate intellectual development as conceptualized by Baxter-Magolda (1992). Felder and Brent suggest that 'science and engineering educators should adopt as a primary goal doing a better job of promoting the intellectual growth of their students than has been done in the past' (2004a, pp. 10-11). Of course, whilst such a goal is desirable its implementation is not simple because so many factors influence intellectual development. For Felder and Brent (2004a), the role of the educator is to provide sufficient challenge to engage students fully, however, this must be done in a supportive manner. An environment which is punitive or hostile towards students who fail in their attempts to voice opinions may only succeed in paralyzing the students thereby effectively halting their intellectual development (Felder \& Brent, 2004b).

\section{Towards a Popperian model of education}

Traditionally science has been taught deductively (Prince \& Felder, 2007) where students are required to learn facts and then taught the importance of these facts through connection with other related facts. The application of these facts is seen as important but secondary. Not only does this fail to help students connect their knowledge to real world problems, it may also fail to teach students how to question and critique knowledge. Many of us have resorted to saying 'just accept [this particular fact] for the moment - you will see its relevance later on'. It has been claimed that science and engineering students are more likely 'believe in the certainty of knowledge and in authority as its source' than their counterparts in the social sciences and humanities (Felder \& Brent, 2004a). In part this is due to the different emphases of the relevant degree programs. The ability to compare and contrast different arguments is considered to be far more important in the social sciences and humanities. These differences may be ameliorated in postgraduate science programs which include seminar style courses (Jehng, Johnson, \& Anderson, 1993) where course material tends to focus on research papers rather than textbooks. Nevertheless, the problem of a relatively simplistic attitude towards knowledge at the end of an undergraduate degree remains. This relatively simplistic attitude is not only problematic for the graduate who ends up in a science related field and is unable to contribute meaningfully in the workplace beyond performing routine lab work, it perpetuates the problem of an uncritical citizenry. For Popper, society can only develop and progress 
through active critical participation (Magee, 1974). If we are to develop a Popperian foundation in undergraduate courses two key elements may help us along the way, inductive teaching methods and peer instruction.

Inductive teaching methods cover a variety of approaches including problem based learning, just-in-time teaching (based on the response to conceptual problems), inquiry based learning, case studies and project based instruction (Prince \& Felder, 2007). The inductive approach clearly utilises Popper's assertion that all learning is problem-solving. The development of critique however, requires student-student interaction, which is often described as peer learning. It is very difficult to participate in a conversation about a specific concept without some process of reflection. The act of articulation of a concept or problem helps students in their intellectual development (Felder \& Brent, 2004a). Whilst it is probable that a student in the physical sciences will not be contesting the validity of a particular understanding of the physical world, they may well contest the validity of the manner in which this concept is articulated by a fellow student. The process of doing so is an important developmental step. Students who are comfortable raising questions amongst their peers may well be more likely to raise questions to the lecturer. The ability to speak in an academic setting is no mean feat. Not only does it require sensitivity to the flow of the discussion, it also requires confidence and fluency (Mann, 2008). These skills are only developed through practice. Practice is far easier in the relatively safe environment of a small peer group. But the conversation will only happen frequently in the small peer group if it is facilitated and necessitated by the structure of the course.

It is only in the last couple of decades that inductive teaching methods have really begun to be explored in the physical sciences. One of the more successful developments appears to be a combination of a use of concept tests and peer instruction (Crouch \& Mazur, 2001). Such an approach does not require the student to develop a sophisticated knowledge of scientific theory from first principles, but rather aids the student in developing an ability to work with the subject matter in a way that has an accurate and robust grounding in conceptual understanding. There is increasing evidence in the literature to show that many undergraduate science majors not only have a simplistic view of knowledge development, they also have far less grasp of the theory of the subject than their marks might suggest. Of course, this points towards the importance of an appropriately aligned assessment - although assessment alone may not deliver substantial improvements in conceptual understanding (Shay, 2008). Nonetheless, evidence has shown that there is a fair correlation between the level at which the basic concepts are grasped and the performance in standard assessments whilst the converse is not necessarily true (Crouch \& Mazur, 2001).

Peer instruction gives students a chance to discuss their understanding of particular concepts or problems. In the process the students are forced to think about what they understand, and to try to articulate that - this requires a process of reflection. The discussion between the students provides a platform in which they can begin to master the art of developing a scientific argument. Finally, the student is forced to face his or her own misconceptions and to rethink and reconsider what he or she understands to be accurate. In this way, the student becomes aware of any problems in conceptual understanding at an early stage and can readily remedy the situation before another layer of theory is added to this platform. In addition, the student is forced into a more sophisticated relationship with knowledge as he comes to recognize that his peers understand and interpret the same information in slightly different ways with varying degrees of accuracy.

Popper leaves one further thought to consider. Ideals can quickly become as stifling as the flawed system they are meant to improve. As we try to implement new systems, issues will emerge that were not anticipated. It crucial therefore, to have a system of critique in place which can periodically assess the new status quo and ascertain the best way forward from this place. If we are to develop better models of science education, we need to adopt better methods of critique.

\section{Conclusion}

At the heart of Popperian philosophy is the idea that critique is the most important way that knowledge, science and society all develop. At the moment, hundreds of thousands of students graduate with science degrees around the world every year. The vast majority of these students have a good grasp of some scientific facts, but tragically this is not necessary coupled with an ability to critique, defend and substantiate a scientific argument. As such, many science graduates may not yet be functional scientists in terms of the way in which they think. If this truly is the case, then it is worth questioning the value of a science degree. Popper provides us with a substantial platform upon which to build a new approach to scientific education. In true Popperian style, it is not clear exactly what that new approach will look like. But the use of concept tests and peer instruction may provide us with a starting point. If these examples, and other similar systems which provide students with a lot of practice at conversation and critique, are used more widely, doubtless new models will emerge. As we engage with trying to develop a truly scientific education for our undergraduates, would do well to remember that, for Popper, problem-solving is not something we have to give to the students. It is an innate quality which we simply must try to uncover. Perhaps it is only if we consciously keep the 
scientist citizen or citizen scientist central in our minds as we develop curricula and argue for the inclusion or exclusion of pockets of information that we will come close to achieving a truly educative science degree. Taking note of a few of the Popperian ideas we may find a way to do that in a manner which is integrated into the science curriculum rather than an added extra.

\section{References}

Altbach, P. G., Reisberg, L., \& Rumbley, L. E. (2009). Trends in global higher education: Tracking an academic revolution: Center for International Higher Education.

Barnett, R. (2008). A will to learn: being a student in an age of uncertainty: Open University Press.

Barnett, R. (2009). Knowing and becoming in the higher education curriculum. Studies in Higher Education, 34(4), 429-440. http://dx.doi.org/10.1080/03075070902771978

Barnett, R., \& Griffin, A. (1997). The end of knowledge in higher education: Cassell.

Barrie, S. C. (2004). A research-based approach to generic graduate attributes policy. Higher Education Research \& Development, 23(3), 261-275. http://dx.doi.org/10.1080/0729436042000235391

Baxter, M. (1992). Knowing and reasoning in college: Gender-related patterns in students' intellectual development: San Francisco: Jossey-Bass.

Becher, T., \& Trowler, P. R. (2001). Academic tribes and territories. Intellectual enquiry and the culture of disciplines, Buckingham: Open University Press.

Bok, D. (2003). Universities in the marketplace: the commercialization of higher education. Princeton, New Jersey: Princeton University Press.

Bourne, S. (2009). Inaugural Address. In University of Cape Town.

Bowden, J., \& Marton, F. (1998). The University of Learning. London: Kogan Page Ltd.

Bricker, L. A., \& Bell, P. (2008). Conceptualizations of argumentation from science studies and the learning sciences and their implications for the practices of science education. Science Education, 92(3), 473-498. http://dx.doi.org/10.1002/sce.20278

Crouch, A. H., \& Mazur, E. (2001). Peer Instruction: Ten years of experience and results. American Journal of Physics, 69(9), 970-977, http://dx.doi.org/ 10.1119/1.1374249.

Dewey, J. (1933). How We Think. New York: Heath and Co.

Dewey, J. (1963). Experience and education. New York: Collier Books.

Edmonds, D., \& Eidinow, J. (2001). Wittgenstein's poker: The story of a ten-minute argument between two great philosophers: Ecco Pr.

Fagen, A. P., Crouch, C. A., \& Mazur, E. (2002). Peer Instruction: Results from a range of classrooms. The Physics Teacher, 40 (4), 206-209. http://dx.doi.org/10.1119/1.1474140

Felder, R. M., \& Brent, B. (2004a). The intellectual development of science and engineering students Part 1. Models and $\begin{array}{lllll}\text { Challenges. } & \text { Journal } & \text { 269-277. }\end{array}$ http://search.proquest.com/docview/217951840?accountid=14049.

Felder, R. M., \& Brent, B. (2004b). The intellectual development of science and engineering students. 2. Teaching to promote growth. Journal of Engineering Education, 93(4), 279-291. http://search.proquest.com/docview/217951483?accountid=14049.

Green, W., Hammer, S., \& Star, C. (2009). Facing up to the challenge: why is it so hard to develop graduate attributes? Higher Education Research \& Development, 28(1), 17-29, http://dx.doi.org/10.1080/07294360802444339.

Hall, D. T. (1996). Protean Careers of the 21st Century. The Academy of Management Executive (1993-2005), 10(4), 8-16. http://dx.doi.org/10.5465/AME.1996.3145315.

Jehng, J.-C. J., Johnson, S. D., \& Anderson, R. C. (1993). Schooling and students' epistemological beliefs and learning. Contemporary Educational Psychology, 18(1), 23-35, http://dx.doi.org/10.1006/ceps.1993.1004.

Liu, O. L. (2009). Measuring value-added in higher education: conditions and caveats: results from using the Measure of Academic Proficiency and Progress (MAPP). Assessment \& Evaluation in Higher Education, 36(1), 81-94, http://dx.doi.org/10.1080/02602930903197917. 
Magee, B. (1974). Popper. London: Woburn Press.

Mann, S. J. (2008). Study, power and the university. Maidenhead, Berks, UK \& New York, NY, USA: Society for Research in Higher Education \& Open University Press.

Marginson, S., \& Rhoades, G. (2002). Beyond national states, markets, and systems of higher education: A glonacal agency heuristic. Higher Education, 43(3), 281-309 Academic Search Premier, EBSCO host (accessed May 2, 2012).

Marton, F., \& Säljö, R. (1984). Approaches to learning. The experience of learning, 36-55.

Maton, K. (2000). Languages of legitimation: The structuring significance for intellectual fields of strategic knowledge claims. British Journal of Sociology of Education, 21(2), 147-167 http://www.jstor.org/stable/1393322.

Maton, K. (2007). Knowledge-knower structures in intellectual and educational fields. In F. Christie \& J. R. Martin (Eds.), Language, knowledge and pedagogy (pp. 87-108). London: Continuum.

Miller, D. (Ed.). (1983). A Pocket Popper. Oxford: Fontana Paperbacks.

Nussbaum, M. C. (2006). Education and democratic citizenship: Capabilities and quality education. Journal of Human Development and Capabilities, 7(3), 385-395, http://dx.doi.org/10.1080/14649880600815974.

Parton, G., \& Bailey, R. (2008). Problem-based learning: A critical rationalist perspective. London Review of Education, 6(3), 281-292. http://dx.doi.org/10.1080/14748460802528475.

Perry, W. G. (1970). Forms of intellectual and ethical development. New York: Holt, Rinehart and Winston.

Popper, K. (1978). Three worlds: The Tanner lecture on human values. In U. o. Michigan (Ed.).

Popper, K. (2002). Conjectures and refutations: The growth of scientific knowledge: Psychology Press.

Prince, M., \& Felder, R. (2007). The many faces of inductive teaching and learning. Journal of College Science Teaching,

http://go.galegroup.com/ps/i.do?id=GALE\%7CA169164826\&v=2.1\&u=27uos\&it=r\&p=AONE\&sw=w.

$36(5)$

Readings, B. (1996). The University in Ruins. Cambridge MA and London UK: Harvard University Press.

Shay, S. (2008). Beyond social constructivist perspectives on assessment: the centring of knowledge. Teaching in Higher Education, 13(5), 595-605. http://dx.doi.org/10.1080/13562510802334970.

Sparks, R. J. (2011). A Value-Added Model To Measure Higher Education Returns On Government Investment. $\begin{array}{llllll}\text { Contemporary Issues } \quad \text { in } \quad \text { Education } & \text { (CIER), } & 4(2),\end{array}$ http://journals.cluteonline.com/index.php/CIER/article/view/4078/4131.

Walker, M. (2008). A human capabilities framework for evaluating student learning. Teaching in Higher Education, 13(4), 477-487. http://dx.doi.org/10.1080/13562510802169764.

West, E. J. (2004). Perry's Legacy: Models of Epistemological Development. Journal of Adult Development, 11(2), 61-70 Academic Search Premier, EBSCO host (accessed May 2, 2012).

Westbrook, R. B. (1993). John Dewey and American Democracy: Cornell University Press.

Note 1. This is a reference to the so-called 'poker incident'. It is alleged that a heated conversation took place between Wittengenstein and Popper in small gathering at Cambridge University in October 1946. Popper's later account of the argument reveals a real difficulty with coping with criticism. 